\title{
Constraint-induced movement therapy が痙縮に与える影響
}

\author{
竹林 崇 ${ }^{1 \dagger}$ \\ 1 吉備国際大学保健医療福祉学部作業療法学専攻 \\ 現大阪府立大学地域保健学域総合リハビリテーション学類作業療法学専攻
}

\begin{abstract}
要旨：脳卒中後の上肢麻瘦とともに後遺症の一つとして痓縮が挙げられる，痤縮は上肢の運動障害の阻害因子とも考元ら れており，この症候群に対するアプローチの確立は急務とされている. American Heart Associationのガイドラインでは, ボッリヌス毒素 $\mathrm{A}$ 型施注や神経筋電気刺激が痓縮の抑制効果に扔いてエビデンスを有している。一方, 課題指向型アプロー チである Constraint-induced movement therapy（CI 療法）については, エビデンスを確立するには至っていないが, 痤縮 抑制の効果抢よびメカニズムを示す論文もある。特にボッリヌス毒素 $\mathrm{A}$ 型施注と併用した際には大きな㾤縮抑制効果を示 すといった論文も認める。本稿では CI 療法の痤縮抑制の疫学的な背景㧍よびメカニズムについて言及するとともに，ボッ リヌス毒素 A 型施注との併用療法の効果についても言及する.
\end{abstract}

キーワード：病縮，CI 療法，ボッリヌス毒素 $\mathrm{A}$ 型施注，上肢機能，脳卒中

\section{1. はじめに}

脳卒中後の $43 \sim 69 \%$ の対象者において, 上肢の運動麻 痺が生じると言われている ${ }^{1,2)}$. さらに, 全患者の $67 \%$ が脳 卒中発症後 4 年後には実生活において麻疩手不使用になる とも言われている ${ }^{1)}$. また, 麻痺手同様に, 脳卒中後の後遺 症の一つに痤縮の悪化がある. 痤縮は発症後徐々に元進し, 発症から 1 ～ 4 ケ月後にピークを迎える ${ }^{3)}$. さらに, 脳卒中 発症から 1 年後には $38 \%$ の対象者に著明な痤縮を認めたと する報告も認められている ${ }^{4)}$. また, 痤縮は身体機能, 活動, 参加の阻害因子になるだけでなく ${ }^{5)}$, 脳卒中発症後 3 ケ月の 時点での機能と活動の回復の阻害因子になるとも報告され ており ${ }^{3)}$. 機能改善を妨げる因子に挙げられている ${ }^{9}$.

この痤縮という症候群に対しては, 従来法ではストレッ チなどのアプローチを実施し，一時的な痤縮の低下に関し ては, 無作為化比較試験などを通しても認めているものの ${ }^{7)}$, American Heart Association（AHA）のリハビリテーション ガイドラインにおいては, 論述すらなされていない ${ }^{8)}$. また, 同ガイドラインの中でも, エビデンスが存在する可能性が あるのは, 脊髄相反抑制機構を用いた痤縮を呈した筋肉の 拮抗筋に対する神経筋電気刺激とボツリヌス毒素 $\mathrm{A}$ 型施注 射が挙げられている ${ }^{8)}$.

2017 年 6 月 20 日受付

${ }^{\dagger}$ × 583-8555 大阪府羽电野市はびきの 3-7-30

大阪府立大学地域保健学域総合リハビリテーション学類作業療法学 専攻

竹林崇

Tel:072-950-2111

E-mail: takshi77@kiui.ac.jp
一方, 近年それらに加えて, 麻疩手に対する集中練習で あり，上記に示した AHA のガイドライン内でもエビデン スレベル A を示されている脳卒中後上肢麻瘏に対する手法 として, Constraint-induced movement therapy（CI 療法）が ある.このアプローチは, 多くの無作為化比較試験におい て, Fugl-Meyer Assessment (FMA) や Wolf Motor Function Test（WMFT）, Action Research Arm Test ど上肢機能およ び能力を示すアウトカムにおいて, 従来法よりも有意な改 善を認めたと,多くの論文において報告されている.ただし， 近年では, 複数の無作為化比較試験において, CI 療法単体 により上肢機能の改善および痤縮減退効果を認めている. さらに, ガイドラインでも推奨されているボッリヌス毒素 $\mathrm{A}$ 型施注と CI 療法を併用することで, 実施後中長期の上肢 機能および痤縮の中長期の改善も確認され始めている.

本稿では, CI 療法およびボッリヌス毒素 $\mathrm{A}$ 型施注併用の $\mathrm{CI}$ 療法の疫学的な視点からの痤縮抑制効果と, 痤縮の抑制 メカニズムについて, 解説を行う.

\section{Cl 療法が痤縮に与える影響}

\section{1 臨床試験から見える Cl 療法が痙縮に与える影響}

Siebers ら ${ }^{9)}$ は, 前向きに生じる連続例を使用したコホー トデザインを用いて，20名の慢性期脳卒中後の対象者に 1 日 6 時間, 1 週間に 7 日の練習を 2 週間の間実施した. 対象 者は従来のCI療法と同様で, 手指 Mettacarpophalangeal(MP) 関節と Interphakangeal（IP）関節の随意伸展が合わせて 10 度以上, 手関節の随意伸展が 20 度以上担保されていること と, 従来の CI 療法では, Modified Ashworth Sccale（MAS） 2 以上の対象者を除外しているが, この研究では MAS2 以 
上の対象者も取り込んでいる. 彼らは, CI 療法前後と CI 療法実施後 6 ケ月後に麻痺側上肢の痤縮の評価として手関 節と肘関節の屈筋群の MAS を測定し, その他, Sallerman Hand Function Test (SHFR) と Motor Activity Log (MAL) を実施している，結果としては，SHFR およびMALについ ては, 介入前後および介入後 6 ケ月にかけて有意な改善を 認めている. 丞縮を示すMASについては, 四 1 から4に示す.

これらを鑑みるとCI 療法による痤縮抑制効果は, MAS3 以上の対象者では, 悪化も認めないが, 改善することもか なり少なく, MAS2 以下の場合で確率的に多くみられるこ とから, 多くの研究が MAS2 以下の対象者を CI 療法の受 け入れ基準に設定していることがうなずける，また，㾏縮 の改善効果は, 上肢機能と同様に, 介入前後だけでなく, 介

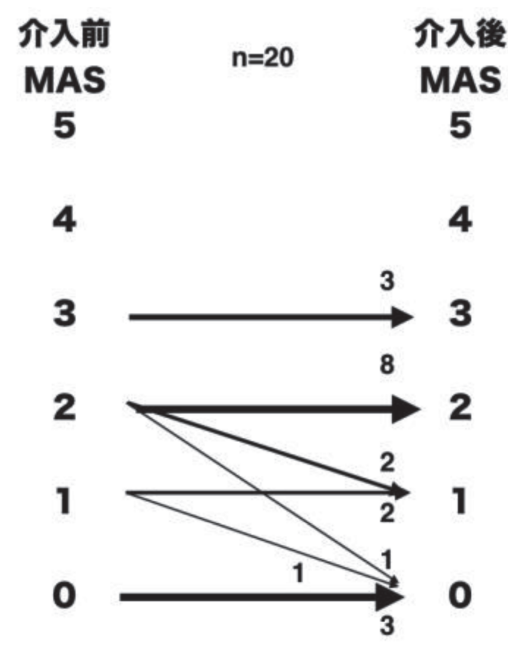

図 1 MAS の介入前後の时関節屈筋の MAS の変化 MAS の変化については, 全ての対象者でMAS の維持もしくは低

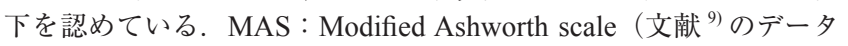
から筆者らが新たに作図).

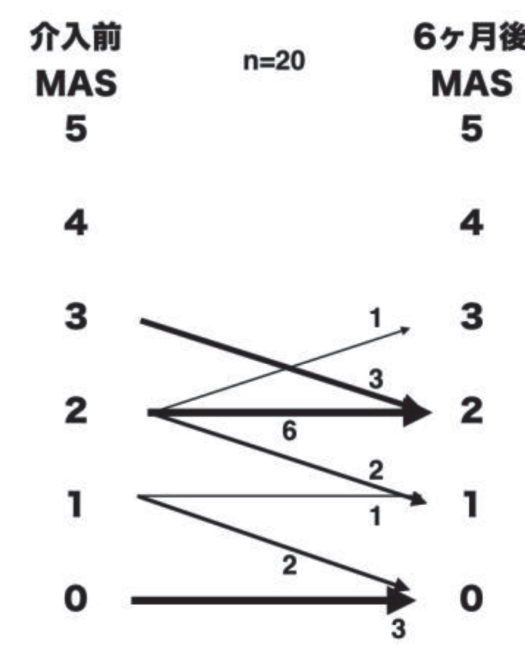

図 2 MAS の介入前から 6 ケ月後の肘関節屈筋の MAS の変化 MAS の変化については. 全ての対象者で MAS の維持もしくは低

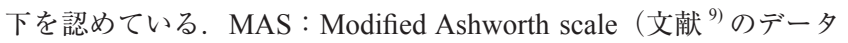
から筆者らが新たに作図).
入後 6 ケ月後にはさらに痓縮が低下している対象者が増加 することが興味深い点である。このように, CI 療法におい ては, 実生活における麻疩手の使用行動が改善することに より，長期的な機能改善が促されることが報告されている. これと同様に, MASについても同様の効能を示すのかもし れない.

さて，上記に示したように，慢性期の脳卒中後に痓縮を呈 した対象者に対して, CI 療法は症縮を低下させる可能性を 示した，それでは他の療法に比べ, 痤縮軽隇効果がどの程 度認められるかについて, いくつかの無作為か比較試験を 検討してみる. Hammer ら ${ }^{11)}$ は, 30 名の亜急性期から慢性 期の対象者に対して, 1 日 2 時間, 週 5 日, 3 週間の Forced use therapy（CI 療法の前身）を実施した群と同時間の一般

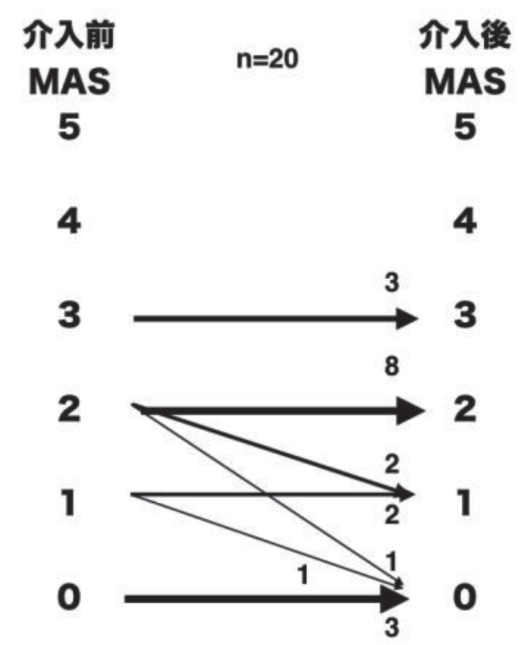

図 3 MAS の介入前後の手関節屈筋の MAS の変化 MAS の変化については, 全ての対象者でMAS の維持もしくは低 下を認めている. MAS：Modified Ashworth scale（文献9)のデー夕 から筆者らが新たに作図).

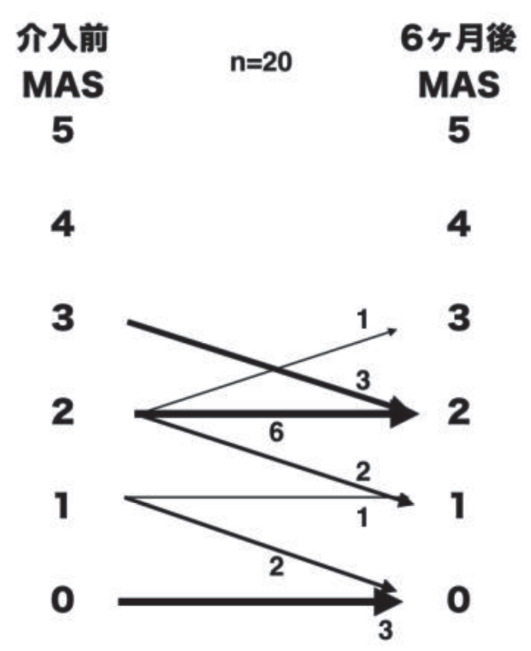

図 4 MAS の介入前後の手関節屈筋の MAS の変化 MAS の変化については, 全ての対象者でMAS の維持もしくは低 下を認めている. MAS : Modified Ashworth scale (文献 ${ }^{9)}$ のデータ から筆者らが新たに作図). 
的なリハビリテーションを実施した群の間で MAS の変化に ついて比較検討したところ, 両群ともに介入前後で MAS は 改善したが, 両群間に有意な差がなかったと報告した.

一方, Smania ら ${ }^{12)}$ は, 亜急性期から慢性期の脳卒中後 の対象者に対して, 1 日 2 時間, 週 5 日, 2 週間の modified CI 療法と, 同時間の従来のリハビリテーションを提供した 結果, 介入直後には MAS の改善は同等であったが, 介入か ら 3 ケ月後において CI 療法を実施した群の MAS の改善が, 従来のリハビリテーションを実施した群に比べ有意に優れ ていたと報告した.

さらに, また, Bang ら ${ }^{13)}$ は, 体幹の正常な動きを引き出 すための聴覚刺激を提供しながら実施した 1 日 1 時間, 週 5 日, 4 週間の modified CI 療法と通常の modified CI 療法を 実施した群の MAS を比較した結果, 両群の MAS に有意な 差は認められなかったと報告している。これらから， CI 療 法および modified CI 療法が従来法に比べて, より明確に㾏 縮を改善することができるといった明確なエビデンスは認 められないものの, 介入前後においては, 痤縮に良影響を 与えることが推測できる。

\section{2. $2 \mathrm{Cl}$ 療法による痙縮減退のメカニズム}

我々 ${ }^{14)}$ は 10 名の慢性期の脳卒中後上肢麻痖を呈した対 象者に対して, 1 日 5 時間, 週 5 日, 2 週間の CI 療法を実 施し, その前後の上肢機能の変化を確認するために, 上肢 機能評価である FMA と WMFT, 実生活における麻痺手の 使用頻度を図る MAL の Amount of use (AOU) を実施した。 さらに, 痤縮の程度を测定するために, MAS に加え, 介入 前後の評価環境を一定に配慮した状況で, 橈側手根屈筋に 関して，電気生理学的手法を用いて測定をした。用いた電 気生理学的手法は, 誘発筋電図を用い, $\alpha$ 運動ニューロン を刺激することにより直接的に筋肉から記録が可能な $\mathrm{M}$ 波, 春髄由来の後期応答（F 波， $\mathrm{H}$ 波）を測定した. $\mathrm{F}$ 波は 10 名の対象者から測定でき, $\mathrm{H}$ 波は 5 名の対象者から測定可 能であった。

まず, F 波について, 小森ら ${ }^{15)}$ は F 波の出現頻度は脊髄 前角細胞で発火する筋繊維とその発火頻度に影響されると 述べている。 よって，80\% 以上を呈した場合はその記録筋 肉の痤縮を示すと考えられている. Liberson ら ${ }^{16)}$ や Fisher ら ${ }^{17)}$ は, F 波振幅は麻痺側で有意に増大し, これが痤縮の 指標になると報告している。 また, 鈴木ら ${ }^{18)}$ は, 振幅 F/M 比が痤縮の程度と強い相関を示したと報告している。この $\mathrm{F}$ 波の出現頻度, 振幅, 振幅 $\mathrm{F} / \mathrm{M}$ 比を $\mathrm{CI}$ 療法前後で比較し た結果, 出現頻度, および振幅 $\mathrm{F} / \mathrm{M}$ 比の全てが有意に低下 したことを報告した。 これらから，CI療法前後において， 脊髄の興奮性の低下が認められ痤縮の減退を認めたことが 推測できる. なお, 図 5 に典型例の CI 療法前後の振幅の变 化について記載するので参考にされたい.

次に, $\mathrm{H}$ 波について, 本研究では $\mathrm{H}$ 波が採集できた対象 者が 5 名であったので, 統計学的な検討には対象者数が少
A

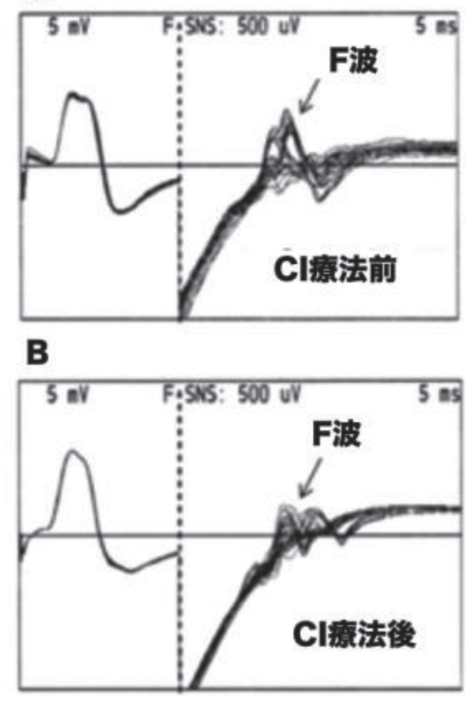

図 $5 \mathrm{CI}$ 療法前後の $\mathrm{F}$ 波の振幅の差 CI 療法前に比べ，後の方が明らかに F 波の振幅の低下が認められ る (文献 ${ }^{14)}$ のデータから筆者らが新たに作図).

なすぎたため，論文には記載していない未発表データとな る. $\mathrm{H}$ 波については, 対象者が 5 名と少ないため, 統計学 的な有意差の信頼性は低いものの, 振幅 H/M 比が介入前後 において, 有意な低下を認めていた. よって, CI 療法によっ て生じた, 過剩な脊髄前角細胞の興奮性の抑制と, I b 群 線維由来のシナプス後抑制の働きにより, 過剩な I a 線維 の興奮性が抑制されたことが, 痤縮の抑制メカニズムの一 端を担っていることが考えられた.

\section{3. ボツリヌス毒素 $\mathrm{A}$ 型施注と Cl 療法}

\section{1 臨床試験からみたボッリヌス毒素 $\mathrm{A}$ 型施注後の $\mathrm{Cl}$ 療 法の影響}

2016 年に AHA が発表したガイドラインにおいてもボッ リヌス毒素 $\mathrm{A}$ 型施注のエビデンスレベルは A と申し分ない. ただし，このエビデンスレベルが示す対象は,「ターゲット となった筋肉の痤縮を低下させる」.「関節可動域を改善し, 更衣動作や手のひらの衛生を保つことができる」であり, 決して脳卒中後の上肢麻疩における機能改善を指している わけではない ${ }^{8)}$. むしろ多くの複数の研究者が,「ボッリヌ ス毒素 $\mathrm{A}$ 型施注自体が能動的な上肢機能を改善させるか, についてはエビデンスが非常にそしい ${ }^{19)} 」$,「ボッリヌス毒 素 $\mathrm{A}$ 型施注のみでは, 電気生理学的な指標に影響を与える ことができたが, 臨床所見を示す MAS では有意な変化を認 めなかった ${ }^{20)} 」$ と報告している.

そこで, ボツリヌス毒素 $\mathrm{A}$ 型施注後にエビデンスが確立 されたアプローチを併用することが推奨されている．例え ば, Levy ${ }^{21)}$ は, 慢性期の脳卒中後上肢麻痺を呈した対象 者に対して，ボッリヌス毒素 $\mathrm{A}$ 型施注を実施しした後，1 日 1 時間, 週 3 回, 4 週間の CI 療法を行った結果, 介入前 
後で, 有意に MAS が改善した（変化量 $: 2$ 点〜 1.2 点）と 報告している.ささらに, Sun ら ${ }^{22)}$ は, 無作為化比較試験に おいて, 32 名の対象者に対して, ボッリヌス毒素 $\mathrm{A}$ 型施注 後に 1 日 2 時間, 週 3 回, 12 週間のプロトコルの CI 療法 を実施した群と同時間の通常のリハビリテーションを実施 した群に割付け比較したところ, 介入から 6 ケ月後の時点 における上肢機能および害生活での使用頻度に加えて, 肘 関節・手関節・手指の屈筋痤縮が有意に改善したことを報 告している（図 6 に両群の肘関節の屈筋の MAS の推移を示 す)。一般的には, ボッリヌス毒素 A 型施注は, 施注から 3 ケ 月程度で効能が失われていることから, その効果を延長す る役割もCI 療法にはあるのかもしれない。 さらに, 近年で はより重度な上肢麻瘏と痓縮を呈した慢性期の脳卒中対象 者に対して,ボッリヌス毒素 A 型施注後に, CI 療法とロボッ 卜療法，そして痓縮の低下にエビデンスが示されつつある 末梢神経筋電気刺激を併用した, 多角的アプローチの報告 23)や，CI 療法実施後に長期的な上肢機能と痓縮が介入終了 後 1 年間改善し続け，CI 療法を併用せず， 3 ケ月毎にボッ リ又ス毒素 $\mathrm{A}$ 型施注を実施した場合に比べると費用対効果 で大きく優れるといった報告 ${ }^{24)}$ などもあり, ボッリ又ス毒 素 A 型施注と CI 療法は非常に相性のよいアプローチである と言える。 また, CI 療法単体では, 無作為化比較試験の結 果を確認すると, 痓縮の抑制効果に扔いて, 他療法よりも 明確に優れているといった知見は少ないが, ボッリ又ス毒 素 A 型施注と併用することで, 痤縮に対する効能は, 明ら かに向上する.この結果からも, 㾏縮に対して, 影響を与 えるアプローチの 1 つと考えることができると考えている.

\section{2 ボツリヌス毒素 A 型施注後の Cl 療法におけるポイン 卜}

前項において, CI 療法は痘縮に対して好影響を与える可 能性と, ボッリヌス毒素 $\mathrm{A}$ 型施注との相性の良さについて, 解説をした。次に, ボッリヌス毒素 A 型実施注と CI 療法を 実施する際のポイントについて, 記載する.

さて, 前述したように, 生活における麻瘢手の使用頻度 を改善することに長けている CI 療法であるが, 長期の機能 改善に扔いても使用頻度が強い因子となっている，痤縮の 長期効果に直接的な影響を与えるか否かについては, 検討 がなされていないのが現状だが，仮に影響を与えうると考 えるならば，この因子を阻害するような振る舞いはできる だけ，排除する方が望ましい．

例えば，ボッリヌス毒素 $\mathrm{A}$ 型施注を望む対象者が,「麻痺 手の機能改善や，実生活に扔ける使用」を希望していた場 合に, 大胸筋の痤縮が高いため, 大容量のボッリヌス毒素 A 型をそこに施注してしまう. すると, 確かに大胸筋の㾏 縮は低下するが, 大胸筋の痓縮によって補われていた肩甲 骨および肩関節周囲の固定性は一気に失われ，施注前まで は挙上できていた肩関節が全く動かなくなってしまう場合 も散見される。 このような状況に陥ると, 対象者のニーズ

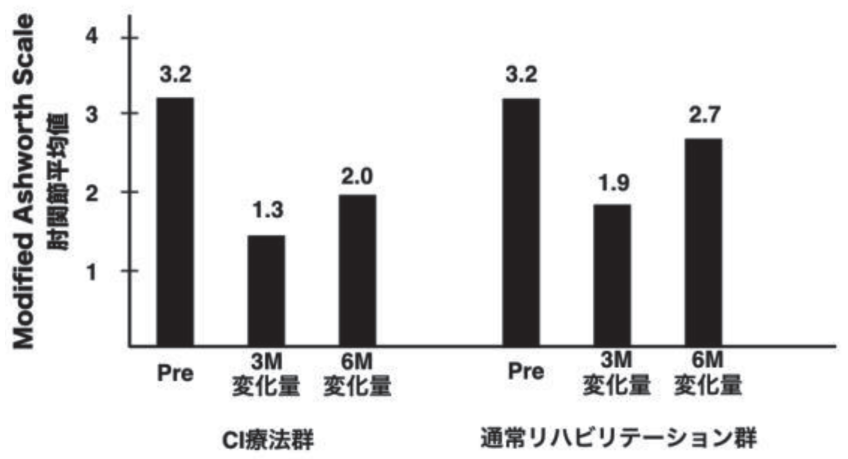

図 6 ボツリヌス $\mathrm{A}$ 型施注実施後の CI 療法群と通常リハビリ テーション群の肘関節 Modified Ashworth Scale の推移 通常療法に比べて, 明らかにCI 療法群の方が短期的な痤縮の改善. 長期的な㽷縮の維持において優れている (文献 ${ }^{21)}$ のデー夕から筆 者らが新たに作図).

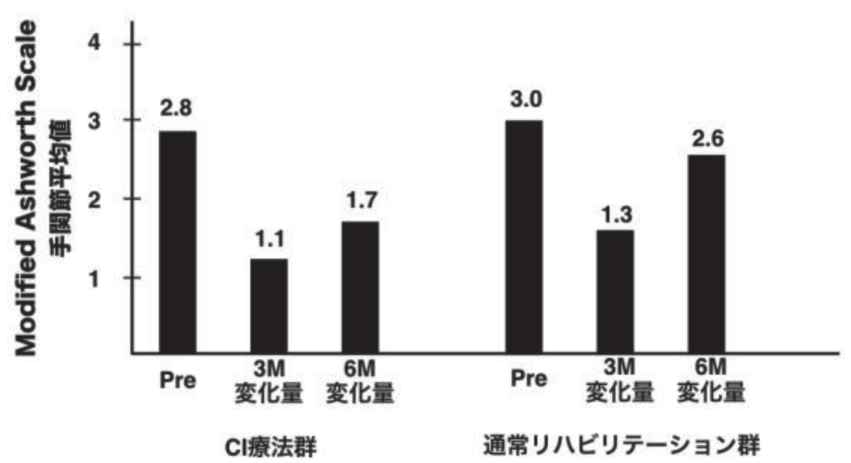

図 7 ボッリ又ス A 型施注実施後の CI 療法群と通常リハビリ テーション群の手関節 Modified Ashworth Scale の推移 通常療法に比べて, 明らかにCI 療法群の方が短期的な痤縮の改善. 長期的な痤縮の維持において優れている (文献 ${ }^{21)}$ のデータから筆 者らが新たに作図).

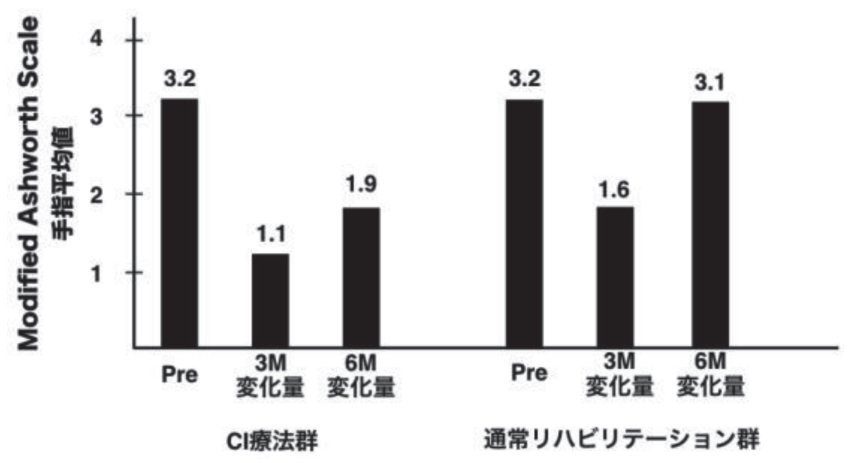

図 8 ボッリ又ス $\mathrm{A}$ 型施注実施後の CI 療法群と通常リハビリ テーション群の手指 Modified Ashworth Scale の推移 通常療法に比べて, 明らかにCI 療法群の方が短期的な痤縮の改善. 長期的な㽷縮の維持において優れている（文献 ${ }^{21)}$ のデータから筆 者らが新たに作図).

である「麻疩手の機能改善や，実生活に扔ける使用」に対 する介入は非常に難しくなる，その結果，3 个月後にはボッ リヌス毒素 $\mathrm{A}$ 型の効能が消失し, 再び同様の施注を繰り返 
すといった悪循環に陥る可能性がある。これらから，ボッ リヌス毒素 $\mathrm{A}$ 型施注の目的が「過剩な痤縮による痛みの軽 減」にあるのか, それとも「麻疩手の機能改善や, 実生活 における使用」にあるのかを確実に確認し，的確に実施す る必要性がある。

\section{謝辞}

非公開部分のデータに関して協力してくださった元兵庫 医科大学医科学専攻高次制御系リハビリテーション科学大 学院生であり, 現特定非営利活動法人リハケア神戸理事長 香川真二先生に深く感謝の意を述べる.

\section{参考文献}

1) Broeks, J. G., Lankhorst, G. J., Rumping, K. and Prevo, A. J.: The long-term outcome of arm function after stroke: results of follow-up study, Disability and Rehabilitation, 21, 357-364, (1999).

2) Nakayama, H., Jorgensen, H. S., Raaschou, H. O. and Olsen, T. S.: Recovery of upper extremity function in stroke patients: the Copenhagen Stroke Study, Archives of Physical Medicine and Rehabilitation, 75, 394-398, (1994).

3) Sommerfeld, D. K., Eek, E. U., Svensson, A. K., Holmqvist, L. W. and von Arbin, M. H.: Spasticity after stroke: its occurrence and association with motor impairments and activity limitations, Stroke, 35, 134-139, (2004).

4) Watkins, C. L., Leathley, M. J., Gregson, J. M., Moore, A. P., Smith, T. L. and Sharma, A. K.: Prevalence of spasticity post stroke, Clinical Rehabilitation, 16, 515-522, (2002).

5) Gregson, J. M., Leathley, M., Moore, A. P, Sharma, A. K., Smith, T. L. and Watkins, C. L.: Reliability of the tone assessment scale and the modified Ashworth scale as clinical tools for assessing poststroke spasticity, Archives of Physical Medicine and Rehabilitation, 80, 1013-1316, (1999).

6) Bhakta, B. B.: Management of spasticity in stroke, British Medical Bulletin, 56, 476-485, (2000).

7) Kim, E. H., Chang, M. C., Seo, J. P., Jang, S. H., Song, J. C. and Jo, H. M.: The effect of a hand stretching device during the management of spasticity in chronic hemiparetic stroke patientws, Annals of Rehabilitation Medicine, 37, 235-240, (2013).

8) Winstein, C. J., Stein, J., Arena, R., Bates, B., Cherney, R. L., Cramer, S. C., Deruyter, D., Eng, J. J., Fisher, B., Harvey, R. L., Lang, C. C. E., MaccKay-Lyons, M., Ottenbaccher, K. J., Pugh, S., Reeves, M. J., Ricchards,
R. L., Stiers, W. and Zorowitz, R. D.: Guidelines for adult stroke rehabilitation and recovery: a guideline for healthcare professionals from the American Heart Association/ American Stroke Association, 47, e98-e169, (2016).

9) Siebers, A., Oberg, U. and Skargren, E.: The effect of modified constraint-induced movement therapy on spasticity and motor function of the affected arm in patients with chronic stroke, Physiotherapy Canada, 62, 388-396, (2010).

10) Takebayashi, T., Amano, S., Hanada, K., Umeji, A., Takahashi, K., Marumoto, K., Kodama, N., Koyama, T. and Domen, K.: A one-year follow-up after modified constraint-induced movement therapy for chronic stroke patients with paretic arm: a prospective case series study, Topics in Stroke Rehabilitation, 22, 18-25, (2015).

11) Hammer, A. M. and Lindmark, B.: Effects of forced use on arm function in the subacute phase after stroke: a randomized, clinical pilot study, Physical Therapy, 89, 529-539, (2009).

12) Smania, N., Gandolfi, M., Paolucci, S. Losa, M., Ianes, P., Recchia, S., Giovanzana, C., Molteni, F., Avesani, R., Di Paolo, P., Zaccala, M., Agostini, M., Tassorelli, C., Fiaschi, A., Primon, D., Cerevolo, M. G. and Farina, S.: Reduced -induced modified constraint-induced movement therapy versus conventional therapy for upper extremity rehabilitation after stroke: a multicenter trial, Neurorehabilitation and Neural Repair, 26, 1035-1045, (2012).

13) Bang, D. H.: Effect of modified constraint-induced movement therapy combined with auditory feedback for trunk control on upper extremity in subacute stroke patients with moderate impairment: randomized controlled pilot trial, Journal of Stroke and Cerebrovascular Diseases, 25, 1606-1612, (2016).

14) Kagawa, S., Koyama, T., Hosomi, M., Takebayashi, T., Hanada, K., Hashimoto, F. and Domen, K.: Effect of constraint-induced movement therapy on spasticity in patients with hemiparesis after stroke, Journal of Stroke and Cerebrovascular Diseases, 22, 364-370, (2013).

15) 小森哲夫, 高橋良輔, 広瀬和彦, 椿忠雄 : F 波の波形と 出現頻度, 臨床脳波, 30, 1-6, (1988).

16) Liberson, W. T., Chen, L. Cc., Fok, S. K., Patel, K. K., Yu, G. H. and Fried, P.: "H" reflexes and "F" waves in hemiplegics, Electromyography and Clinical Nurophysiology, 17, 247-264, (1977).

17) Fisher, M. A.: F response analysis of motor disorders of central origin, Journal of the Neurological Sciences, 62, 13-22, (1983). 
18）鈴木俊明, 八瀬善郎, 藤原哲司, 大工谷新一, 廣瀬浩昭: $\mathrm{F}$ 波出現を認めなかった脳血管障害片麻痺患者の神経生 理学的特性, 理学療法学, 24, 102-107, (1997).

19) Sheean, G., Lannin, N. A., Turner-Stokes, L., Rawicki, B. and Snow, B. J.: Botulinumn toxin assessment, intervention and after-care for upper limb hypertonicity in adults: international consensus statement, European Journal of Neurology, 2, 74-93, (2010).

20) Intiso, D., Simone, V., Di Rinzo, F., Santamato, A., Russo, M., Tolfa, M. and Bascciani, M.: Dose spasticity reduction by botulinum toxin type A improve upper limb functionality in adult post-stroke patients? A systematic review of relevant studies, Journal of Neurology and Neurophysiology, 4, 167, (2013).

21) Levy, C. E., Giuffrida, C., Ricchards, L., Wu, S., Davis, S. and Nadeau, S. E.: Botulinum toxin A, evidencebased exercise therapy, and constraint-induced movement therapy for upper-limb hemiparesis attributable to stroke: a preliminary study, American Journal of Physical Medicine \& Rehabilitation, 86, 698-706, (2007).

22) Sun, S. F., Hsu, C. W., Sun, H. P., Hwang, C. W., Yang, C. L. and Wang, J. L.: Combined botulinum toxin type A with modified constraint-induced movement therapy for chronic stroke patients with upper extremity spasticity: a randomized controlled study, Neurorehabilitation and Neural Repair, 24, 34-41, (2010).
23) Takebayashi, T., Amano, S., Hanada, K., Umeji, A., Takahashi, K., Koyama, T. and Domen, K.: Therapeuticc synergism in the treatment of post-stroke arm paresis utilizing botulinum toxin, robotic therapy, and constraintinduced movement therapy, PM\&R, 6, 1054-1058, (2014).

24) Amano, S., Takebayashi, T., Hanada, K., Umeji, A., Marumoto, K., Furukawa, K. and Domen, K.: Constraintindued movement therapy after injection of botulinum toxin type A for a patient with chronic stroke: One-Year follow-up case report, Physical Therapy, 95, 1039-1045, (2015).

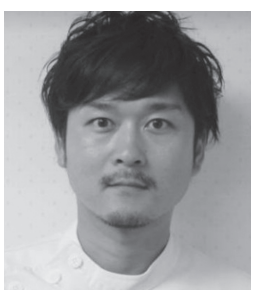

竹林 崇（たけばやしたかし）

2003 年川崎医療福祉大学医療技術学部 リハビリテーション学科作業療法専攻卒 業後, 兵庫医科大学病院リハビリテー ション部に就職する. その後, 2012 年に University of Alabama, Birmingham にて, CI therapy training course を修了. 2013 年にて大阪府立大学 地域保健学域総合リハビリテーション学類大学院総合リハ ビリテーション学研究科博士前期課程修了. 2018 年兵庫医 科大学医科学専攻高次神経制御系リハビリテーション科学 にて, 博士 (医学) を取得. 同年 10 月より大阪府立大学地 域保健学域総合リハビリテーション学類作業療法学専攻准 教授に就任. 